\title{
FAKTOR-FAKTOR PENENTU UTAMA KETERLAMBATAN PADA PEKERJAAN KONSTRUKSI PABRIK (STUDI KASUS: PABRIK KAWASAN CIKARANG)
}

\author{
Mardiaman ${ }^{1}$, Indriasari ${ }^{2}$ \\ ${ }^{1}$ Jurusan Teknik Sipil, Universitas Tama Jagakarsa \\ Email: mardi240967@gmail.com \\ ${ }^{2}$ Teknik Sipil Fakultas Teknik Universitas Krisnadwipayana \\ indriasari@unkris.ac.id
}

Masuk: 27-03-2021, revisi: 19-04-2021, diterima untuk diterbitkan: 30-04-2021

\begin{abstract}
ABSTRAK
Waktu menjadi pertimbangan pada setiap tahap pekerjaan dalam proyek konstruksi. Peristiwa keterlambatan sering terjadi pada berbagai pekerjaan konstruksi. Berbagai faktor mempengaruhi waktu pelaksanaan pekerjaan konstruksi. Selanjutnya faktor tersebut berkontribusi terhadap waktu pelaksanaan. Penelitian ini menstudi secara mendalam tentang urutan faktor penyebab keterlambatan pekerjaan konstruksi. Daftar faktor-faktor keterlambatan dikumpulkan dari berbagai sumber literatur dan pengalaman. Setelah melakukan penyaringan maka dihasilkan 6 kategori dan 57 faktor keterlambatan berturut turut: 1) tenaga kerja (13 faktor); 2) bahan (5); 3) peralatan (7); 4) karakteristik lokasi (10); 5) manajerial (16); dan 6) keuangan (6). Faktor-faktor ini disusun ke dalam daftar kuesioner terstruktur yang selanjutnya diisi oleh responden menurut kecenderungan persepsi mereka. Jumlah responden sebanyak 34 dan sudah berpengalaman. Ada 5 skala persepsi: tidak berpengaruh diberi nilai 1, kurang berpengaruh (2), sedang (3) berpengaruh (4), sangat berpengaruh (5). Penyebaran melalui tatap muka dan google form. Data terkumpul untuk menentukan rangking faktor menggunakan analisa nilai rata rata berdasarkan nilai besar ke kecil. Untuk menguji keandalan dan validitas data dilakukan uji Cronbach alpha. Hasil olahan data berdasarkan kategori penyebab keterlambatan diperoleh urutan: bahan; tenaga kerja; manajerial; karakteristik tempat; keuangan: dan peralatan. Sementara 3 faktor tertinggi meliputi: pengiriman bahan $\left(\mathrm{B}_{1}\right)$; kurang koordinasi dengan pengawas $\left(\mathrm{A}_{10}\right)$ dan keperluan penghitungan material $\left(\mathrm{E}_{4}\right)$. Penting bagi kontraktor yang mendapatkan pekerjaan di kawasan cikarang dan di tempat lainnya memperhatikan 3 faktor utama yang berkontribusi terhadap terjadinya keterlambatan pada pekerjaan bangunan industri.
\end{abstract}

Kata kunci: kategori; faktor keterlambatan; industri pabrik; rata-rata; ranking.

\begin{abstract}
At every stage of a construction project, time is a factor. Delays are common in construction projects. The timing of construction projects is influenced by a number of factors. Furthermore, these factors contribute to the length of time required for implementation. The sequence of factors that cause delays in construction work is examined in depth in this study. The list of delay factors compiled from various sources. Following the screening, the following 6 categories and 57 factors of tardiness were generated in order: 2) ingredients (5); 3) equipment (7); 4) location characteristics (10); 5) managerial (16); and 6) finance (6). These factors were arranged into a structured questionnaire list, which respondents filled out based on their perception trends. A total of 34 people responded to the survey. The Cronbach alpha test was used to test the reliability and validity of the collected data, which was used to determine the factor ranking using average value analysis based on large to small values. The data was processed in the following order based on the categories of the delay's causes: ingredients; labor; managerial; location characteristics; finance; and equipment. Meanwhile, material delivery (B1), a lack of coordination with supervisors (A10), and the need for material counting are the three most important factors (E4). Contractors looking for work in Cikarang and elsewhere should be aware of three major factors that cause delays in industrial construction projects.
\end{abstract}

Keywords: category; tardiness factor; factory industry; average; ranking.

\section{PENDAHULUAN}

Pekerjaan konstruksi sifatnya sangat tidak pasti. Waktu selesainya setiap item pekerjaan dalam lingkup proyek bisa cepat dan lambat. Keterlambatan pekerjaan konstruksi menyebabkan kerugian pada pemilik dan kontraktor. Ada berbagai sumber, kategori dan faktor yang berkontribusi sebagai penyebab terjadinya keterlambatan. Faktor penyebab keterlambatan 


\section{Mardiaman, Indriasari, Faktor-Faktor Penentu Utama Keterlambatan Pada Pekerjaan Konstruksi Pabrik (Studi Kasus: Pabrik Kawasan Cikarang)}

pada berbagai pekerjaan konstruksi sudah banyak dibahas diantaranya pada pekerjaan air bawah tanah (Frimpong, Oluwoye, \& Crawford, 2003); infrastruktur (Asmi \& Pratama, 2016), bangunan gedung (Handayani, Frederika, \& Wiranata, 2013), jalan (Remon F. Aziz \& AbdelHakam, 2016); bangunan industri (Farooqui \& Umer, 2012a). Penyebab keterlambatan yang ada akan berbeda-beda menurut jenis, fungsi, ukura dan kompleksitas pekerjaan konstruksi. Faktor-faktor penyebab keterlambatan pada proyek pelaksanaan kawasan pabrik mempunyai phenomena tersendiri (Wirabakti, Abdulah dan Maddeppungeng 2014); (Asmi \& Pratama, 2016); (Hassan, Mangare, \& Pratasis, 2016); (Sulaiman, 2017). Penyebab keterlambatan dapat berasal dari pihak kontraktor, sub kontraktor, konsultan dan pemilik (Almutairi, 2016). Sehingga komunikasi diantara pihak-pihak ini mendapat perhatian yang penting. Penempatan tenaga kerja sesuai dengan kompetensi dari pihak terkait harus tepat.

Berbagai metode penentuan rangking penyebab keterlambatan pekerjaan konstruksi sudah dilakukan seperti metode relative importance index (RII) dan dampak kritisnya dengan korelasi oleh (Gebrehiwet \& Luo, 2017); (Almutairi, 2016); (Farooqui \& Umer, 2012b); analisis reliabilitas, validitas dan analisis frequency index (Sulaiman, 2017). Indeks rata-rata (Al-Emad, Abdul Rahman, Nagapan, \& Gamil, 2017)

Kawasan Cikarang-EJIP (East Java Interantional Plan) merupakan kawasan industri yang terus berkembang dengan tingkat pengembangan industri yang terus bertambah. Pada kawasan tersebut diproduksi bermacam-macam produk seperti kawat baja pra-tekanan dan helai, kawat baja, kawat baja dan helai baja galvanis, batang dan kabel aluminium. Pabrik berlokasi di Lippo Cikarang Industrial Estate dengan luas lahan $\pm 49,729 \mathrm{~m}^{2}$. Komposisi bangunan yang ada di kawasan: Industri sebesar (68\%), apartemen (18\%) dan perkantoran (15\%). Kondisi kawasan (gambar 1).

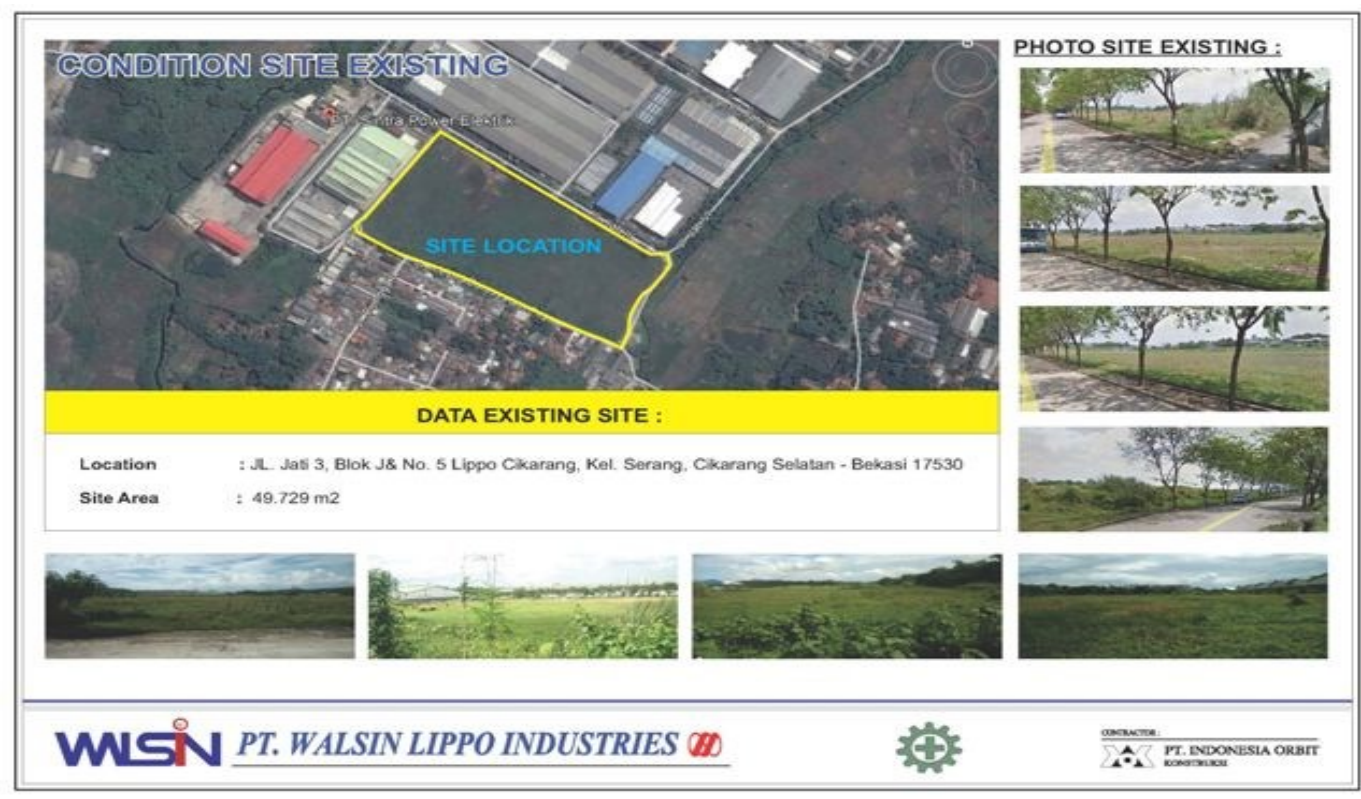

Gambar 1 Kondisi Kawasan

Melihat banyak dan kompleksnya pembangunan pada kawasan industri mengakibatkan pelaksanaan pekerjaan diperkirakan terlambat. Penelitian untuk mengetahui faktor apa yang menjadi penyebab utama keterlambatan pada pembangunan Pabrik di di kawasan Cikarang perlu dilakukan. 


\subsection{Proyek Konstruksi}

Tahap kegiatan konstruksi secara umum meliputi: 1) perencanaan, 2) pengorganisasian, 3) pelaksanaan, pengendalian. (Hassan et al., 2016). Proyek konstruksi bersifat tidak pasti dan memerlukan sumber daya. Ketersediaan sumberdaya bahan, peralatan, tenaga kerja dan pendanaan harus tersedia dalam jumlah dan waktu yang tepat. Sumber daya bahan menyerap kira-kira 50-70\% dari biaya total proyek, manusia, peralatan sebesar 10,317\% untuk bangunan bertingkat (Mardiaman, 2020b) dan uang. Pendanaan berasal dari swasta, pemerintah atau gabungan keduanya. Uang digunakan untuk pengadaan sumber daya menurut item kegiatan yang sudah dijadwalkan sesuai penentuan progres rencana. Rencana kegiatan sudah disepakati oleh pihak terkait. Kesuksesan pekerjaan konstruksi sangat bergantung pada kinerja keuangan kontraktor (Mardiaman, 2020a). Kategori bahan mencakup: bahan rekayasa dan bahan curah, bahan permanen, bahan sementara. Pemilihan bahan dan alat bergantung pada fungsi dan jenis konstruksi, kebutuhan pemilik. peraturan, lokasi, dana yang tersedia. Proyek konstruksi dikategorikan:1) konstruksi gedung, rekayasa berat, industri pabrik. Rangkaian kegiatan konstruksi hanya satu kali, ada waktu awal dan akhir kegiatan.

\subsection{Dampak Keterlambatan Proyek}

Evaluasi terhadap jadwal waktu mutlak dilakukan pada saat pelaksanaan konstruksi. Penyesuaian dilakukan jika perlu untuk mengakomodasi perubahan, Tujuannya untuk mengatasi sinkronisasi apa yang sudah disiapkan dan target progres, sehingga keterlambatan dapat dikurangi (Hassan et al., 2016). Jadwal konstruksi awal mengacu pada yang sudah disiapkan sebelum pekerjaan dimulai dan disetujui oleh pemilik. (Le-Hoai, Lee, \& Lee, 2008) menyatakan bahwa keterlambatan merupakan penambahan waktu di luar tanggal yang disepakati dalam kontrak atau yang disepakati pihak-pihak yang terlibat dalam proyek. Keterlambatan merupakan peristiwa bertambahnya waktu yang diperlukan.

Berbagai konsekuensi keterlambatan meliputi terjadi klaim perpanjangan waktu, kompensasi moneter atau keduanya. Keterlambatan berdampak pada perencanaan awal, masalah finansial. Selanjutnya dampak keterlambatan pada pemilik meliputi hilangnya keuntungan dari fasilitas yang dibangun, sedangkan bagi kontraktor adalah hilangnya peluang menggunakan sumber dayanya ke proyek lain, meningkatnya biaya tidak langsung.

Keterlambatan menyebabkan kerugian. Bagi pemilik, keterlambatan menimbukan hilangnya pendapatan dari bangunan yang harusnya sudah bisa digunakan. Selanjutnya bagi kontraktor, keterlambatan proyek berarti bertambahnya biaya overhead karena perpanjangan waktu pelaksanaan. Dalam hal ini mungkin ada kenaikan biaya sumber daya tenaga kerja, peralatan. Selain itu terjadi pengurangan modal kontraktor, yang seharusnya dapat digunakan untuk proyek lain. Bagi konsultan, keterlambatan akan menyebabkan hilangnya waktu. Penundaan menyebabkan konsultan akan terhambat dalam merencanakan proyek lain. Lebih jauh (Alifen, Setiawan, \& Susanto, 2000) berpendapat bahwa dampak dari keterlambatan proyek menimbulkan kerugian pada pihak kontraktor, konsultan, dan pemilik. Terakhir (Aziz, 2015) menjelaskan akibat umum keterlambatan 1) penyelesaian proyek terlambat, 2) biaya meningkat, 3) terganggunya pekerjaan, 4) berkurangnya produktivitas, 5) tuntutan pihak ketiga, 6) penolakan hasil kerja, 7) pemutusan kontrak

\subsection{Faktor-Faktor Penyebab Keterlambatan Pekerjaan Konstruksi}

Berbagai penelitian tentang sumber dan faktor keterlambatan telah dilakukan terhadap berbagai jenis proyek konstruksi. (Shahsavand, 2018) berpendapat bahwa sumber utama keterlambatan proyek konstruksi bersumber dari 1) pemilik; 2) kontraktor; 3) konsultan; 4) disain; 5) bahan; 6) pekerja dan peralatan; 7) eksternal. Rangking faktor keterlambatan 


\section{Mardiaman, Indriasari, Faktor-Faktor Penentu Utama Keterlambatan Pada Pekerjaan Konstruksi Pabrik (Studi Kasus: Pabrik Kawasan Cikarang)}

didasarkan pada persepsi konsultan, kontraktor dan pemilik dengan metode relatif penting dan keuntungan dan kerugiannya (Almutairi, 2016). (Al-Emad, Rahman, Nagapan, \& Gamil, 2017) menambahkan urutan teratas faktor utama keterlambatan meliputi: koordinasi antar pihak terkait, kekurangan tenaga kerja, keterlambatan penyediaan dokumen, perencanaan dan penjadwalan kurang akurat, terlambat pembayaran, tingkat produktivitas tenaga kerja, tenaga kerja tidak berkualitas, pengelolaan kontrak kerja kurang baik.

(Hassan et al., 2016) menyatakan keterlambatan karena terjadi perubahan bentuk fungsi, spesifikasi, lambatnya pengiriman bahan, kerusakan peralatan, ketersedian keuangan, keterlambatan pembayaran oleh owner, kesalahan disain, kekurangan tenaga kerja, kemampuan tenaga kerja, perbedaan jadwal sub kontraktor. Berikutnya Sulaiman, Munirwansyah, \& Ameri, 2017) menambahkan terlambat lelang, ketelitian jadwal. Selanjutnya (Ismi, Pratama, \& Safrilah, 2016) menambahkan perubahan disain, kesulitan keuangan pemilik, pembayaran terlambat, keterlambatan jadwal, sub kontraktor kurang kompeten. Wirabakti, Abdulah, menambahkan masalah keuangan, tenaga kerja keterampilan, bahan, dan manajemen. (Al-Emad, Rahman, Nagapan, \& Gamil, 2017) menjelaskan 10 faktor utama penyebab keterlambatan proyek industri konstruksi meliputi: keuangan kontraktor terganggu, buruknya koordinasi, kurangnya tenaga kerja, terlambat disain dibuat, buruknya perencanaan dan jadwal, keterlambatan pembayaran, rendahnya tingkat produktivitas pekerja, tenaga kerja tidak berkualitas dan manajemen kontrak buruk..

(Jackson, 2002) penyebab keterlambatan konstruksi di Ilorin adalah faktor fluktuasi harga bahan, tenaga kerja, dapat proyek tidak tetap, terlambat honor pekerja, analisa kurang tepat dalam proses penawaran proyek, pemilihan kontraktor kurang kompeten, penawaran harga tidak tepat dan permintaan dari pemilik yang selalu berubah. Jackson (2002) penyebab keterlambatan pekerjaan konstruksi di Inggris penambahan dana pada saat perubahan disain, perubahan desain, ketersediaan informasi, metoda dari estimasi, performa dari tim disain dan manajemen proyek. (Farooqui \& Umer, 2012b) menambahkan 10 faktor utama keterlambatan: fluktuasi harga material, biaya tinggi untuk perawatan mesin, penawaran yang terlalu rendah, prosedur pengadaan barang dan material, phasa pengadaan, metode dari perkiraan biaya yang tidak tepat, tambahan kerja, perencanaan yang tidak tepat Selanjutnya (Andrew Shing-Tao Chang 2002) menambahkan kebijakan pemerintah yang kurang mendukung.

Faktor-faktor yang mempengaruhi keterlambatan waktu pelaksanaa proyek berasal dari kontraktor, pemilik, dan selain kedua belah pihak. (Hassan et al., 2016) menyatakan keterlambatan akibat kesalahan kontraktor: a) terlambat memulai pelaksanaan proyek, b) pekerja dan pelaksana kurang pengalaman.c). peralatan terlambat datang, d) mandor yang kurang aktif, e) rencana kerja yang kurang baik.

Keterlambatan terjadi akibat kesalahan Owner: a) terlambatnya angsuran pembayaran oleh kontraktor, b) terlambatnya penyedian lahan, c) mengadakan perubahan pekerjaan yang besar, d) pemilik menugaskan kontraktor lain untuk mengerjakan proyek tersebut. Sementara keterlambatan mengerjakan proyek disebabkan oleh beberapa faktor dijelaskna oleh (Wirabakti, Abdulah, \& Maddeppungeng, 2014)

\section{METODE}

Penelitian dilakukan selama periode Agustus s/d Desember 2020. Data primer berupa daftar kategori dan faktor-faktor keterlambatan dalam pelaksanaan pekerjaan konstruksi dikumpulkan dari sumber literatur dan wawancara. Setiap faktor diberi kode khusus. Ada 6 kategori dan 57 faktor dirangkum yang mempengaruhi keterlambatan pada pekerjaan konstruksi pada kawasan industri. 
1. Tenaga kerja: kurangnya tenaga ahli $\left(\mathrm{A}_{1}\right)$; kurangnya tenaga terampil $\left(\mathrm{A}_{2}\right)$; jam kerja $\left(\mathrm{A}_{3}\right)$; usia pekerja $\left(A_{4}\right)$; budaya $\left(A_{5}\right)$; kurang disiplin dalam bekerja $\left(A_{6}\right)$; kurang termotivasi $\left(A_{7}\right)$; angka kehadiran kurang ( $\left.\mathrm{A}_{8}\right)$; penggantian pekerja baru (A9); kurang koordinasi dengan pengawas $\left(A_{10}\right)$; kecelakaan tenaga kerja $\left(A_{11}\right)$; kurang pengalaman di bidangnya $\left(A_{12}\right)$; moral yang rendah $\left(\mathrm{A}_{13}\right)$

2. Bahan: proses pengiriman barang $\left(B_{1}\right)$; stok ketersediaan barang $\left(B_{2}\right)$; kualitas bahan $\left(B_{3}\right)$; perubahan dan spesifikasi material $\left(\mathrm{B}_{4}\right)$.

3. Peralatan: ketersediaan peralatan $\left(\mathrm{C}_{1}\right)$; kualitas peralatan $\left(\mathrm{C}_{2}\right)$; masa pemakaian alat $\left(\mathrm{C}_{3}\right)$; suku cadang $\left(\mathrm{C}_{4}\right)$; perawatan alat $(\mathrm{C} 5)$; alokasi peralatan/jumah peralatan $\left(\mathrm{C}_{6}\right)$; efisiensi dan produktivitas pemakaian alat $\left(\mathrm{C}_{7}\right)$.

4. Karakteristik lokasi: tempat penyimpanan bahan $\left(D_{1}\right)$; akses ke lokasi proyek $\left(D_{2}\right)$; kebutuhan ruang kerja $\left(\mathrm{D}_{3}\right)$; lokasi proyek $\left(\mathrm{D}_{4}\right)$; keadaan permukaan dan bawah tanah $\left(\mathrm{D}_{5}\right)$; pengaruh lingkungan sekitar $\left(\mathrm{D}_{6}\right)$; karakteristik fisik dan bangunan sekitar lokasi proyek $\left(D_{7}\right)$; luas pekerjaan $\left(D_{8}\right)$; fasilitas proyek $\left(D_{9}\right)$; kemiringan tanah $\left(D_{10}\right)$.

5. Manajerial: pengawasan proyek $\left(E_{1}\right)$; kualitas pengontrolan pekerjaan $\left(E_{2}\right)$; pengalaman manajer lapangan $\left(\mathrm{E}_{3}\right)$; keperluan penghitungan material $\left(\mathrm{E}_{4}\right)$; perubahan disain $\left(\mathrm{E}_{5}\right)$; komunikasi antara konsultan dan kontraktor $\left(\mathrm{E}_{6}\right)$; Komunikasi antara kontraktor dan pemilik $\left(\mathrm{E}_{7}\right)$; jadwal pengiriman material dan peralatan $\left(\mathrm{E}_{8}\right)$; jadwal pekerjaan yang harus diselesaikan $\left(\mathrm{E}_{9}\right)$; persiapan/penetapan rancangan tempat $\left(\mathrm{E}_{10}\right)$; perubahan lingkup pekerjaan $\left(E_{11}\right)$; kesalahan dan tidak konsistennya dokumen $\left(E_{12}\right)$; lama mengambil keputusan di dalam pekerjaan $\left(E_{13}\right)$; terlambatnya persetujuan $\left(E_{14}\right)$; terlambatnya inspeksi pekerjaan $\left(\mathrm{E}_{15}\right)$; metode konstruksi ( $\left.\mathrm{E}_{16}\right)$; persiapan/penempatan tenaga kerja $\left(\mathrm{E}_{17}\right)$.

6. Keuangan: pembayaran oleh pemilik kepada kontraktor $\left(\mathrm{F}_{1}\right)$; inflasi harga material $\left(\mathrm{F}_{2}\right)$; sistem pembayaran $\left(\mathrm{F}_{3}\right)$; kegiatan proyek $\left(\mathrm{F}_{4}\right)$; pemakaian dana $\left(\mathrm{F}_{5}\right)$; terlambatnya pembayaran kontraktor kepada mandor $\left(\mathrm{F}_{6}\right)$.

Faktor-faktor yang ada disusun dalam lembar pertanyaan terstruktur untuk diminta diisi oleh responden terpilih berdasarkan persepsi mereka masing-masing. Pengumpulan sampel dengan purposive sampling sebanyak 34 orang. Sampel responden terpilih orang yang sudah pernah bekerja pada pekerjaan konstruksi di kawasan industri Cikarang. Penyebaran kuesioner dilakukan secara tatap muka dan Whatsapp. Form kuesioner yang ditulis dalam google.docs dikirim bagi responden pengguna Whatsapp. Pengumpulan data isian berlangsung selama 1 bulan penuh.

Responden memberi nilai berdasarkan persepsi mereka masing-masing menggunakan skala likert, Nilai persepsi menurut skala data order: tidak berpengaruh diberi nilai 1, kurang berpengaruh (2), sedang (3) berpengaruh (4), sangat berpengaruh (5). Selanjutnya setiap faktor dianalisa urutan pengaruhnya mulai terbesar ke terkecil.

Analisa data penentuan rangking faktor menggunakan nilai rata-rata dan simpangan baku. Nilai simpangan baku semakin kecil menunjukkan bahwa faktor dinyatakan semakin menentukan.

Mean ranking

$\mathrm{M}_{\mathrm{r}}=\frac{\sum_{\mathrm{i}=1}^{\mathrm{n}} \mathrm{x}_{\mathrm{i}}}{\mathrm{n}}$

Simpangan baku

$\sigma=\sqrt{\frac{\sum_{i=1}^{n}\left(x_{i}-\bar{x}\right)^{2}}{n-1}}$

dimana :

$\mathrm{M}_{\mathrm{r}} \quad$ = Nilai rata-rata ( Mean )

$\mathrm{n} \quad=$ Jumlah responden 
Mardiaman, Indriasari, Faktor-Faktor Penentu Utama Keterlambatan Pada Pekerjaan Konstruksi Pabrik (Studi Kasus: Pabrik Kawasan Cikarang)

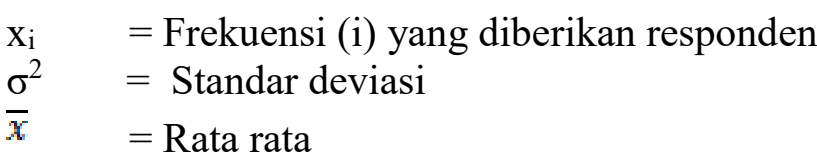

\section{HASIL DAN DISKUSI}

Berdasarkan hasil pengumpulan data diperoleh jumlah persentase pengalaman kerja responden : $1 \mathrm{~s} / \mathrm{d} 5$ tahun (41\%), $6 \mathrm{~s} / \mathrm{d} 10$ tahun (21\%) dan lebih dari 10 tahun (38\%).

\subsection{Uji Validitas dan Reliabilitas}

Uji realibilitas untuk mengetahui konsistensi hasil pengukuran jika instrumen digunakan kembali sebagai alat untuk mengukur responden. Hasil uji reliabilitas mencerminkan tingkat stabilitas dan akurasi instrumen pengukuran yang diperoleh. Uji reliabilitas dengan menggunakan nilai Cronbach yang mencerminkan ukuran sebenarnya dari suatu pengukuran. Ada 5 skala pengukuran berdasarkan urutannya mulai dari kurang reliabilitas sampai sangat reliabilitas sesuai dengan nilai cronbath alpaha (tabel 1).

Tabel 1. Skala Alpha Cronbach 0 sampai 1.

\begin{tabular}{cccc}
\hline No & Keterangan & Nilai Alpha & Reliabilitas \\
\hline 1. & Nilai Alpha Cronbach & $0.00-0.20$ & Kurang reabel \\
\hline 2. & Nilai Alpha Cronbach & $0.21-0.40$ & Agak reabel \\
\hline 3. & Nilai Alpha Cronbach & $0.41-0.60$ & Cukup reabel \\
\hline 4. & Nilai Alpha Cronbach & $0.61-0.80$ & Reabel \\
\hline 5. & Nilai Alpha Cronbach & $0.81-1$ & Sangat reabel \\
\hline
\end{tabular}

Sumber: Olahan data

Pengujian reliabilitas dan validitas data menggunakan software SPSS dengan cara melihat nilai dan tanda $(r)$ : Bila $r$ hitung negatif, maka butir pertanyaan tidak valid, jika $(r)$ hitung $<(r)$ tabel, maka butir pertanyaan tidak valid dan bila positif dimana (r) hitung $>$ (r) tabel, maka butir pertanyaan valid. Dari hasil uji validitas dan reabilitas bahwa semua pertanyaam masuk kategori sangat reliabel.

Table 2. Nilai Alpha Cronbach

\begin{tabular}{cccccccccc}
\hline No & $\begin{array}{c}\text { Scale } \\
\text { mean } \\
\text { skala }\end{array}$ & $\begin{array}{c}\text { Variasi } \\
\text { skala }\end{array}$ & $\begin{array}{c}\text { Total } \\
\text { item } \\
\text { terkoreksi }\end{array}$ & $\begin{array}{c}\text { Nilai } \\
\text { Cronbach's } \\
\text { Alpha }\end{array}$ & No & $\begin{array}{c}\text { Scale } \\
\text { mean } \\
\text { skala }\end{array}$ & $\begin{array}{c}\text { Variasi } \\
\text { skala }\end{array}$ & $\begin{array}{c}\text { Total } \\
\text { item } \\
\text { terkoreksi }\end{array}$ & $\begin{array}{c}\text { Nilai } \\
\text { Cronbach's } \\
\text { Alpha }\end{array}$ \\
\hline $\mathrm{A}_{1}$ & 105.2647 & 318.019 & 0.460 & 0.928 & $\mathrm{D}_{3}$ & 104.7059 & 314.881 & 0.504 & 0.928 \\
\hline $\mathrm{A}_{10}$ & 105.0882 & 315.477 & 0.530 & 0.928 & $\mathrm{D}_{4}$ & 104.5588 & 311.890 & 0.641 & 0.927 \\
\hline $\mathrm{A}_{11}$ & 104.4118 & 320.734 & 0.198 & 0.931 & $\mathrm{D}_{5}$ & 104.6471 & 314.357 & 0.477 & 0.928 \\
\hline $\mathrm{A}_{12}$ & 104.1765 & 321.907 & 0.191 & 0.930 & $\mathrm{D}_{6}$ & 104.8235 & 313.665 & 0.544 & 0.927 \\
\hline $\mathrm{A}_{13}$ & 105.2941 & 322.881 & 0.216 & 0.930 & $\mathrm{D}_{7}$ & 104.6765 & 315.074 & 0.486 & 0.928 \\
\hline $\mathrm{A}_{2}$ & 104.9706 & 316.151 & 0.444 & 0.928 & $\mathrm{D}_{8}$ & 104.5882 & 312.371 & 0.533 & 0.928 \\
\hline $\mathrm{A}_{3}$ & 105.2353 & 319.216 & 0.375 & 0.929 & $\mathrm{D}_{9}$ & 105.0588 & 315.209 & 0.456 & 0.928 \\
\hline $\mathrm{A}_{4}$ & 104.7059 & 318.881 & 0.347 & 0.929 & $\mathrm{E}_{1}$ & 105.1765 & 314.816 & 0.627 & 0.927 \\
\hline $\mathrm{A}_{5}$ & 105.3235 & 324.892 & 0.181 & 0.930 & $\mathrm{E}_{2}$ & 105.0000 & 317.818 & 0.372 & 0.929 \\
\hline $\mathrm{A}_{6}$ & 105.1471 & 316.129 & 0.430 & 0.928 & $\mathrm{E}_{3}$ & 104.8235 & 307.604 & 0.644 & 0.927 \\
\hline $\mathrm{A}_{7}$ & 105.0294 & 322.696 & 0.199 & 0.930 & $\mathrm{E}_{4}$ & 104.9118 & 313.356 & 0.545 & 0.927 \\
\hline $\mathrm{A}_{8}$ & 104.8529 & 317.038 & 0.344 & 0.929 & $\mathrm{E}_{5}$ & 105.1765 & 320.816 & 0.312 & 0.929 \\
\hline $\mathrm{A}_{9}$ & 105.3529 & 325.084 & 0.170 & 0.930 & $\mathrm{E}_{6}$ & 105.0588 & 321.936 & 0.283 & 0.929 \\
\hline $\mathrm{B}_{1}$ & 105.2941 & 321.608 & 0.293 & 0.929 & $\mathrm{E}_{7}$ & 104.9118 & 313.840 & 0.598 & 0.927 \\
\hline $\mathrm{B}_{2}$ & 105.0588 & 313.027 & 0.648 & 0.927 & $\mathrm{E}_{8}$ & 104.8235 & 309.907 & 0.568 & 0.927 \\
\hline $\mathrm{B}_{3}$ & 104.9412 & 309.815 & 0.752 & 0.926 & $\mathrm{E}_{9}$ & 104.8235 & 318.695 & 0.349 & 0.929 \\
\hline $\mathrm{B}_{4}$ & 104.9118 & 320.022 & 0.397 & 0.929 & $\mathrm{E}_{10}$ & 105.0882 & 321.598 & 0.292 & 0.929 \\
\hline
\end{tabular}




\begin{tabular}{cccccccccc}
\hline $\mathrm{B}_{5}$ & 105.2059 & 316.290 & 0.471 & 0.928 & $\mathrm{E}_{11}$ & 105.0882 & 318.931 & 0.507 & 0.928 \\
\hline $\mathrm{C}_{1}$ & 104.8824 & 323.622 & 0.207 & 0.930 & $\mathrm{E}_{12}$ & 105.2353 & 320.064 & 0.405 & 0.929 \\
\hline $\mathrm{C}_{2}$ & 104.6176 & 316.668 & 0.499 & 0.928 & $\mathrm{E}_{13}$ & 105.0000 & 319.697 & 0.302 & 0.929 \\
\hline $\mathrm{C}_{3}$ & 104.6471 & 317.569 & 0.470 & 0.928 & $\mathrm{E}_{14}$ & 105.0000 & 316.000 & 0.441 & 0.928 \\
\hline $\mathrm{C}_{4}$ & 104.7353 & 314.140 & 0.585 & 0.927 & $\mathrm{E}_{15}$ & 105.0882 & 322.325 & 0.194 & 0.930 \\
\hline $\mathrm{C}_{5}$ & 105.0000 & 312.727 & 0.600 & 0.927 & $\mathrm{E}_{16}$ & 104.9118 & 317.962 & 0.349 & 0.929 \\
\hline $\mathrm{C}_{6}$ & 104.9706 & 315.605 & 0.576 & 0.927 & $\mathrm{~F}_{1}$ & 105.2647 & 322.140 & 0.270 & 0.929 \\
\hline $\mathrm{C}_{7}$ & 104.8529 & 319.463 & 0.420 & 0.928 & $\mathrm{~F}_{2}$ & 104.9412 & 327.815 & 0.013 & 0.931 \\
\hline $\mathrm{D}_{1}$ & 105.0294 & 319.181 & 0.359 & 0.929 & $\mathrm{~F}_{3}$ & 105.0588 & 314.602 & 0.506 & 0.928 \\
\hline $\mathrm{D}_{10}$ & 104.8529 & 315.826 & 0.475 & 0.928 & $\mathrm{~F}_{4}$ & 104.7941 & 312.532 & 0.516 & 0.928 \\
\hline $\mathrm{D}_{2}$ & 104.9706 & 312.939 & 0.568 & 0.927 & & & & & \\
\hline $\mathrm{S}_{4}$ & & & & & & & &
\end{tabular}

Sumber: hasil olahan data

\subsection{Analisa Ranking Faktor}

Rangking semua faktor keterlambatan pekerjaan konstruksi industri di kawasan Cikarang (tabel 3). Faktor yang memiliki nilai simpangan baku terkecil menempati urutan pertama dengan nilai $(0,50664)$ diikuti oleh kurang koordinasi dari pekerja konstruksi dengan pengawas (.50752) dan keperluan perhitungan material (.51102)

Tabel 3. Rangkin faktor pada pekerjaan konstruksi industri di kawasan Cikarang

\begin{tabular}{|c|c|c|c|c|c|c|c|c|c|c|c|}
\hline No & Min & Max & Mean & $\begin{array}{l}\text { Simp } \\
\text { Baku }\end{array}$ & urutan & No & Min & Max & Mean & $\begin{array}{l}\text { Simp } \\
\text { baku }\end{array}$ & urutan \\
\hline $\mathrm{B}_{1}$ & 1.00 & 2.00 & 1.4706 & .50664 & 1 & $\mathrm{D}_{6}$ & 1.00 & 4.00 & 2.2647 & .70962 & 30 \\
\hline $\mathrm{A}_{10}$ & 1.00 & 2.00 & 1.5000 & .50752 & 2 & $\mathrm{C}_{6}$ & 1.00 & 3.00 & 1.8235 & .71650 & 31 \\
\hline$E_{4}$ & 1.00 & 3.00 & 1.7353 & .51102 & 3 & $\mathrm{D}_{3}$ & 1.00 & 4.00 & 1.9706 & .71712 & 32 \\
\hline $\mathrm{E}_{5}$ & 1.00 & 3.00 & 1.5882 & .55692 & 4 & $\mathrm{D}_{5}$ & 1.00 & 4.00 & 2.1176 & .72883 & 33 \\
\hline $\mathrm{B}_{5}$ & 1.00 & 3.00 & 1.9118 & .57036 & 5 & $\mathrm{~A}_{9}$ & 1.00 & 4.00 & 2.1176 & .72883 & 34 \\
\hline $\mathrm{D}_{1}$ & 1.00 & 3.00 & 1.9706 & .57658 & 6 & $\mathrm{~A}_{12}$ & 1.00 & 3.00 & 1.7941 & .72944 & 35 \\
\hline $\mathrm{F}_{3}$ & 1.00 & 3.00 & 1.8824 & .59108 & 7 & $\mathrm{D}_{8}$ & 1.00 & 4.00 & 2.0000 & .73855 & 36 \\
\hline$E_{2}$ & 1.00 & 3.00 & 1.6471 & .59708 & 8 & $F_{1}$ & 1.00 & 4.00 & 2.0000 & .73855 & 37 \\
\hline $\mathrm{C}_{2}$ & 1.00 & 3.00 & 1.9412 & .60006 & 9 & $\mathrm{~F}_{4}$ & 1.00 & 3.00 & 1.7647 & .74096 & 38 \\
\hline$E_{14}$ & 1.00 & 3.00 & 1.7647 & .60597 & 10 & $\mathrm{D}_{9}$ & 1.00 & 4.00 & 2.1471 & .74396 & 39 \\
\hline $\mathrm{C}_{7}$ & 1.00 & 3.00 & 1.8529 & .60964 & 11 & $\mathrm{~A}_{7}$ & 1.00 & 3.00 & 1.8529 & .74396 & 40 \\
\hline $\mathrm{A}_{2}$ & 1.00 & 3.00 & 1.5588 & .61255 & 12 & $\mathrm{D}_{4}$ & 1.00 & 4.00 & 1.8529 & .74396 & 41 \\
\hline $\mathrm{F}_{2}$ & 1.00 & 3.00 & 1.5588 & .61255 & 13 & $E_{12}$ & 1.00 & 4.00 & 1.9118 & .75348 & 42 \\
\hline $\mathrm{B}_{2}$ & 1.00 & 3.00 & 1.5294 & .61473 & 14 & $\mathrm{E}_{10}$ & 1.00 & 5.00 & 1.8235 & .75761 & 43 \\
\hline$E_{3}$ & 1.00 & 3.00 & 1.7353 & .61835 & 15 & $\mathrm{E}_{6}$ & 1.00 & 4.00 & 1.8235 & .75761 & 44 \\
\hline $\mathrm{C}_{4}$ & 1.00 & 3.00 & 2.1765 & .62622 & 16 & $E_{7}$ & 1.00 & 4.00 & 1.8235 & .75761 & 45 \\
\hline $\mathrm{C}_{3}$ & 1.00 & 4.00 & 2.2059 & .64099 & 17 & $\mathrm{~A}_{11}$ & 1.00 & 3.00 & 1.6765 & .76755 & 46 \\
\hline$E_{13}$ & 1.00 & 3.00 & 1.6471 & .64584 & 18 & $E_{1}$ & 1.00 & 4.00 & 1.7647 & .78079 & 47 \\
\hline $\mathrm{B}_{3}$ & 1.00 & 4.00 & 1.7647 & .65407 & 19 & $E_{8}$ & 1.00 & 5.00 & 1.7353 & .79043 & 48 \\
\hline $\mathrm{A}_{8}$ & 1.00 & 3.00 & 1.5882 & .65679 & 20 & $\mathrm{E}_{9}$ & 1.00 & 5.00 & 1.9118 & .79268 & 49 \\
\hline $\mathrm{A}_{1}$ & 1.00 & 3.00 & 1.4118 & .65679 & 21 & $\mathrm{D}_{7}$ & 1.00 & 4.00 & 2.1765 & .79661 & 50 \\
\hline $\mathrm{A}_{6}$ & 1.00 & 3.00 & 1.5294 & .66220 & 22 & $\mathrm{D}_{10}$ & 1.00 & 4.00 & 2.2353 & .81868 & 51 \\
\hline $\mathrm{A}_{3}$ & 1.00 & 3.00 & 1.7353 & .66555 & 23 & $\mathrm{~F}_{5}$ & 1.00 & 4.00 & 2.0294 & .83431 & 52 \\
\hline $\mathrm{C}_{5}$ & 1.00 & 3.00 & 2.0882 & .66822 & 24 & $\mathrm{~A}_{5}$ & 1.00 & 4.00 & 2.6471 & .84861 & 53 \\
\hline$E_{15}$ & 1.00 & 3.00 & 1.9118 & .66822 & 25 & $\mathrm{~A}_{13}$ & 1.00 & 4.00 & 1.9706 & .86988 & 54 \\
\hline $\mathrm{B}_{4}$ & 1.00 & 4.00 & 1.8824 & 68599 & 26 & $E_{11}$ & 1.00 & 5.00 & 2.0000 & .88763 & 55 \\
\hline $\mathrm{F}_{6}$ & 1.00 & 3.00 & 1.7941 & .68664 & 27 & $\mathrm{E}_{16}$ & 1.00 & 4.00 & 2.0000 & .88763 & 56 \\
\hline $\mathrm{D}_{2}$ & 1.00 & 3.00 & 1.7941 & .68664 & 28 & $\mathrm{~A}_{4}$ & 1.00 & 4.00 & 2.4118 & .95719 & 57 \\
\hline $\mathrm{C}_{1}$ & 1.00 & 4.00 & 1.6176 & .69695 & 29 & & & & & & \\
\hline
\end{tabular}

Sumber: Hasil Analisa, 2020 


\section{Mardiaman, Indriasari, Faktor-Faktor Penentu Utama Keterlambatan Pada Pekerjaan Konstruksi Pabrik (Studi Kasus: Pabrik Kawasan Cikarang)}

\subsection{Diskusi}

Pada proyek pekerjaan konstruksi industri di kawasan industri Cikarang ada berbagai faktor penyebab keterlambatan. Dari kategori bahan diperoleh pengiriman bahan $\left(\mathrm{B}_{1}\right)$ sebagai faktor pertama yang menyebabkan keterlambatan. Pengiriman bahan terlambat tiba di lokasi dapat disebabkan kesulitasn akses jalan. Jalan menuju ke lokasi mempunyai tingkat kepadatan lalu lintas cukup tinggi. Hasil ini menunjukkan bahwa faktor $\mathrm{B}_{1}$ berlaku juga pada kasus pekerjaan konstruksi lain oleh (Hassan et al., 2016). Kelancaran akses masuk secara umum dipengaruhi oleh beberapa hal misalnya jumlah lalu lintas, jam puncak atau tidak, ada perbaikan jalan, keramaian. Pengenalan akses masuk dapat memudahkan dalam pengiriman sumber daya keburuhan proyek.

Keterlambatan pada proyek ini larena pada saat bersamaan ada pembangunan konstruksi jalan elevated tol arah Bekasi - Cikampek. Pada saat itu ada pemberlakuaan jam masuk kendaraan, sehingga ada penyempitan ruas jalan dan pengalihan jalur lalu lintas. Hal ini mengakibatkan waktu tempuh menjadi lebih lama. Pengaturan waktu pengiriman bahan harus dilakukan pada malam hari yang kepadatan lalu lintasnya kecil.

Tenaga kerja; faktor kurang koordinasi pekerja konstruksi dengan pengawas $\left(\mathrm{A}_{10}\right)$ masuk urutan ke 2. Pada pekerjaan ada pihak terkait kontraktor dan konsultan pengawas terlibat. Koordinasi dilakukan pada setiap pertemuam mingguan yang sudah terjadwal sementara rapat lapangan dilakukan di lapangan. Apa saja yang akan dilaksanakan sudah dibuat pada rencana harian dan mingguan. Antara konsultan pengawas dan kontraktor bekerja sesuai yang disepakati dan berkoordinasi jika perubahan kerja.

Koordinasi kurang baik berdampak pada terjadinya kesalahan metode kerja karena ada salah perintah kerja, penggunaan bahan, perubahan disain. Pekerjaan berulang sering terjadi karena salah komunikasi berdampak pada keterlambatan eksekusi. Penempatan tenaga kerja bauk di konsultan dan pengawas berdasarkan kompetensi seharusnya menjadi perhatian khusus. Koordinasi berjalan apabila orang yang berkomunikasi paham terhadap apa yang dikomunikasikan, Penempatan tenaga kerja yang kurang baik berkontribusi pada terjadinya kesalah pahaman dalam pekerjaan antara keinginan kontraktor dengan pengawas dan pemilik. Dalam penelitiannya (Al-Emad et al., 2017) menyatakan kurang koordinasi antar pihak-pihak terkait dan kualitas tenaga kerja sangat berpengaruh pada terjadinya keterlambatan pelaksanaan pekerjaan konstruksi. Tenaga kerja seharusnya tersedia dalam jumlah dan kompetensi yang tepat untuk bisa melakukan komunikasi dua arah. Pemahaman yang sama antara pihak terkait baik kontraktor, pengawas dan pemilik akan memperlancar pekerjaan. Sebaliknya kamunikasi yang buruk antara pihak terkait berakibat pada saling menyalahkan, susah mengambil keputusan yang membuang waktu. Komunikasi yang efektif perlu dilakukan sesuai kebutuhan komunikasi, komunikasi dua arah, kejelasan isi pesan, kejujuran berkomunikasi, dan resolusi konflik (Saputra, Kadar Yanti, Wiguna, \& Nurcahyo, 2017) . Dengan dilakukannya semua indikator komunikasi akan memuluskan pekerjaan konstruksi

Manajerial: terdapat 2 faktor menempati urutan 3 dan 4 yaitu keperluan perhitungan material ( $\left.\mathrm{E}_{4}\right)$ dan perubahan disain $\left(\mathrm{E}_{5}\right)$. Keperluan perhitungan material kurang dikomunikasikan menyebabkan keterlambatan proyek konstruksi. Jumlah material bisa kekurangan sehingga harus dipesan ulang akibat estimasi penggunaan bahan salah sesuai aktualnya. Kekurangan bahan menjadi faktor utama oleh (Hassan et al., 2016). Berikutnya perubahan disain terjadi dalam pekerjaan konstruksi dimana tidak tepatnya perencanaan dan teknis pekerjaan di lapangan akibat perencana yang tidak profesional dalam bekerja, atau seringnya penggantian disain oleh owner. Gambar disain ulang membutuhkan waktu lagi 
sehingga pekerjaan terganggu waktu mulainya. Pelaksanaan didasarkan gambar kerja yang sudah disepakati antara perencana, kontraktor dan pengawas sesuai aturan berlaku.

Karakteristik tempat: dimana faktor tempat penyimpanan bahan $\left(\mathrm{D}_{1}\right)$ manjadi urutan ke 5 , dan menjadi urutan pertama di dalam kategorinya. Keadaan ini terjadi karena ada penumpukan datangnya bahan, sementara tempat yang tersedia sangat terbatas. Pengaturan tibanya bahan yang akan dipakai disesuaikan dengan jadwal yang sudah ada sehinggga penumpukan bahan di lokasi dapat dihindari. Pengelolaan lokasi untuk penempatan peralatan, gudang, dan titik mulai kerja menentukan kecepatan aksesibilitas. Penempatan bahan berpengaruh terhadap kecepatan kerja yang meningkatkan produktivitas, sebaliknya jika salah dapat memperlambat pekerjaan (Nadiasa $^{1}$, Diah, Dewi ${ }^{1}, \&$ Pameka $^{2}$, 2014). Hasil ini menunjukkan bahwa faktor ini dapat terjadi (Gebrehiwet \& Luo, 2017). Peletakan posisi bangunan dan sarana pendukungnya yang berpengaruh pada sirkulasi alat. manusia dan bahan. Hal ini berkaitan dengan bentuk permukaan lokasi (Al-Hazim, Salem, \& Ahmad, 2017). Percepatan pekerjaan dapat dicapai dengan optimalisasi tata letak fasilitas pendukung pelaksanaan (Siahaan, Sugiyarto, \& Sunarmasto, 2018)

Keuangan: sistem pembayaran $\left(\mathrm{F}_{3}\right)$ menempati urutan ke-6. Sistem pembayaran antara pemilik dan kontraktor, kontraktor dan sub kontraktort/supplier, kontraktor dengan mandor dan pekerja. Sering terjadi keterlambatan pembayaran. Meskipun sebenarnya jadwal pembayaran sudah disepakati antara pihak-pihak terkait, namun pemilik sering melakukan pembayaran tidak tepat waktu. Ini menyebabkan kontraktor tidak dapat menyediakan dana dalam mengadakan sumber daya yang dibutuhkan. Keluarnya uang oleh kontraktor untuk mengejar jadwal sesuai rencana untuk pengadaan sumber daya. Progres merupakan uang yang harus dikeluarkan oleh kontraktor. Dapat dinyatakan bahwa kesulitan pendanaan berpengaruh terhadap kinerja kecepatan pelaksanaan konstruksi (Asmi \& Pratama, 2016)

Memang benar bahwa kontraktor sudah berjanji dalam kontrak untuk melaksanakan semua pekerjaan, namun dalam kontrak sudah dituliskan sistem pembayaran apakah berdasarkan waktu atau bobot progres. Terlambatnya pembayaran dapat terjadi akibat administrasi pembayaran belum berjalan, ada permasalahan pendanaan dari pemilik. Jadi faktor ketersediaan dana merupakan hal penting. Dalam penelitiannya (Remon Fayek Aziz, 2013) menyatakan bahwa faktor pendanaan masuk dalam 9 faktor teratas.

Peralatan: kualitas peralatan $\left(\mathrm{C}_{2}\right)$ masuk urutan ke-7 dan urutan tertinggi dalam kategorinya. Alat yang kurang layak berdampak pada produktivitas rendah dimana alat sering tidak bekerja karena rusak, lambat kerjanya. Tingkat penggunaan alat rendah karena tidak berfungsi secara efektif dimana efisiensi alat mengalami penurunan seiring bertambahnya waktu terutama jika alat tidak dipemelihara secara rutin. Perencanaan peralatan merupakan solusi dalam mempercapat pekerjaan dengan memilih alat yang sesuai (Putri \& Hartono, 2020)

\section{KESIMPULAN}

1. Berdasarkan kategori penyebab keterlambatan diperoleh urutan: bahan; tenaga kerja; manajerial; karakteristik tempat; keuangan: dan peralatan. Sementara 3 faktor tertinggi meliputi: pengiriman bahan $\left(\mathrm{B}_{1}\right)$; kurang koordinasi dengan pengawas $\left(\mathrm{A}_{10}\right)$ dan keperluan penghitungan material $\left(\mathrm{E}_{4}\right)$. Pengiriman bahan secara tepat waktu disesuaikan dengan kebutuhan yang sudah dilaporkan oleh pengawas sesuai dengan perhitungan perkiraan bahan kebutuhan setiap harinya sebaiknya dipastikan pada rapat mingguan,

2. Urutan pertama adalah faktor proses pengiriman bahan material terjadi karena ada pengaturan akses masuk ke lokasi akibat ada pembangunan elevated tol menuju lokasi Pengaturan bahan material diutamakan pada aktivitas yang saling bergantung yang ada pada 


\section{Mardiaman, Indriasari, Faktor-Faktor Penentu Utama Keterlambatan Pada Pekerjaan Konstruksi Pabrik (Studi Kasus: Pabrik Kawasan Cikarang)}

lintasan kritis yang sudah dibuat oleh scheduler pada master schedule. Komunikasi dengan bagian pengadaan material dari kantor pusat harus terjaga untuk memastikan bahan dipesan tepat waktu.

3. Akses menuju lokasi merupakan jalur lalu lintas yang cukup padat sehingga pengaturan jam pengiriman bahan seharusnya dilakukan pada malam hari pada saat kepadatan lalu lintas relatif kecil. Informasi tentang akses masuk ke lokasi proyek seharusnya sudah diketahui sehinggan waktu penyelesaian proyek dapat diperhitungkan secara tepat.

\section{UCAPAN TERIMA KASIH}

Penelitian ini dapat saya selesai berkat bantuan, dorongan dan motivasi para rekan sejawat dan universitas tama jagakarsa yang memberikan bantuan untuk pembiayaan penelitian. Selanjutnya saya berterima ksih pada saudara vicky dalam penyebaran kuesioner.

\section{DAFTAR PUSTAKA}

Al-Emad, N., Abdul Rahman, I., Nagapan, S., \& Gamil, Y. (2017). Ranking of Delay Factors for Makkah's Construction Industry. MATEC Web of Conferences, 103, 0-7. https://doi.org/10.1051/matecconf/201710303001

Al-Hazim, N., Salem, Z. A., \& Ahmad, H. (2017). Delay and Cost Overrun in Infrastructure Projects in Jordan. Procedia Engineering, 182, 18-24. https://doi.org/10.1016/j.proeng.2017.03.105

Almutairi, N. S. (2016). Causes of delays on Construction Projects in Kuwait according to opinion of engineers working in Kuwait. Interntional Journal of Engineering Research and Application, 6(12 (Part 3)), 84-96. Retrieved from www.ijera.com

Asmi, A., \& Pratama, J. C. S. (2016). Identifikasi Faktor-Faktor Keterlambatan Dalam Proyek Konstruksi Di Jakarta. Jurnal, (November), 1-12.

Aziz, Remon F., \& Abdel-Hakam, A. A. (2016). Exploring delay causes of road construction projects in Egypt. Alexandria Engineering Journal, 55(2), 1515-1539. https://doi.org/10.1016/j.aej.2016.03.006

Aziz, Remon Fayek. (2013). Ranking of delay factors in construction projects after Egyptian revolution. Alexandria Engineering Journal, 52(3), 387-406. https://doi.org/10.1016/j.aej.2013.03.002

Farooqui, R. U., \& Umer, M. (2012a). Factors Affecting Construction Cost in the Pakistani Construction Industry. In Third International Conference on Construction in Developing Countries (ICCIDC-III) "Advancing Civil, Architectural and Construction Engineering \& Managemen (pp. 161-168).

Farooqui, R. U., \& Umer, M. (2012b). Factors Affecting Construction Cost in the Pakistani Construction Industry, (July), 161-168.

Frimpong, Y., Oluwoye, J., \& Crawford, L. (2003). Causes of delay and cost overruns in construction of groundwater projects in a developing countries; Ghana as a case study. International Journal of Project Management, 21(5), 321-326. https://doi.org/10.1016/S0263-7863(02)00055-8

Gebrehiwet, T., \& Luo, H. (2017). Analysis of Delay Impact on Construction Project Based on RII and Correlation Coefficient: Empirical Study. In Procedia Engineering. https://doi.org/10.1016/j.proeng.2017.07.212

Handayani, R., Frederika, A., \& Wiranata, A. A. (2013). Analisis Faktor-faktor Penyebab Keterlambatan Pelaksanaan Pekerjaan Proyek Gedung di Kabupaten Jembrana (Studi Kasus: Pembangunan Proyek Gedung di Kabupaten Jembrana). Jurnal Ilmiah Elektronik Infrastruktur Teknik Sipil, 2(1), VII-1-VII-7. Retrieved from 
http://ojs.unud.ac.id/index.php/jieits/article/viewFile/5095/3882

Hassan, H., Mangare, J. B., \& Pratasis, P. A. K. (2016). Faktor-faktor penyebab keterlambatan pada proyek konstruksi dan alternatif penyelesaiannya (studi kasus: di manado town square III). Jurnal Sipil Statik Vol.4, 4(11), 657-664.

Jackson, S. (2002). Project Cost Overruns and Risk Management. Proceedings of Association of Researchers in Construction Management 18th Annual ARCOM Conference, Newcastle, Northumber University, UK, 1(September), 1-10. Retrieved from http://www.reading.ac.uk/web/FILES/innovativeconstructionresearchcentre/icrc-31-cProjectcostoverrunsandriskmanagementARCOM2002.pdf

Le-Hoai, L., Lee, Y. D., \& Lee, J. Y. (2008). Delay and cost overruns in Vietnam large construction projects: A comparison with other selected countries. KSCE Journal of Civil Engineering, 12(6), 367-377. https://doi.org/10.1007/s12205-008-0367-7

Mardiaman. (2020a). Dettermining Weight Criteria/Sub-Criteria In Selecting Public Construction Work Contractor . Palarch's Journal Of Archaeology Of Egypt/Egyptology, 17(9), 9485-9495. Retrieved from https://archives.palarch.nl/index.php/jae/article/view/5910/5786

Mardiaman. (2020b). Proportion Of Resource Component Cost In Multi-Story Buildings : Indonesia Case. Solid State Technology, 63(5), 5785-5794.

Nadiasa, M., Diah, A. A., Dewi, P., \& Pameka, S. (2014). Analisis Pengaruh Lokasi Terhadap Biaya Proyek Irigasi (Studi Kasus : Pengangkutan Material Ke Lokasi Proyek Irigasi Di Kabupaten Gianyar). Jurnal Ilmiah Teknik Sipil, 18(2), 130-136.

Putri, M. K., \& Hartono, W. (2020). Pengaruh rantai pasok peralatan terhadap keberhasilan proyek konstruksi bangunan gedung di wilayah surakarta menggunakan regresi linear berganda 1), 152-159.

Remon Fayek Aziz. (2013). Ranking of delay factors in construction projects after Egyptian revolution. Alexandria Engineering Journal, 52(3), 387-406. https://doi.org/10.1016/j.aej.2013.03.002

Saputra, A. A. I., Kadar Yanti, R. M., Wiguna, I. P. A., \& Nurcahyo, C. B. (2017). Pengaruh Komunikasi Terhadap Keberhasilan Proyek Pada Hubungan Kerja Antara Kontraktor dan Subkontraktor. JST (Jurnal Sains Terapan), 3(2), 87-95. https://doi.org/10.32487/jst.v3i2.265

Siahaan, E., Sugiyarto, S., \& Sunarmasto, S. (2018). Optimalisasi Tata Letak Fasilitas Pada Proyek Pembangunan Gedung Sudirman Suite Jakarta Menggunakan Metode Multi Objectives Function. Matriks Teknik Sipil, 6(2), 360-366 . https://doi.org/10.20961/mateksi.v6i2.36576

Sulaiman, M. (2017). Analisis Penyebab Keterlambatan Pelaksanaan Proyek Ditinjau Dari Waktu Pelaksanaan Di Provinsi Aceh. Jurnal Teknik Sipil, 1(2), 405-418 